Elena Bogdanova

\title{
RUSSIAN SOS CHILDREN'S VILLAGES AND DEINSTITUTIONALISATION REFORM: BALANCING BETWEEN INSTITUTIONAL AND FAMILY CARE
}

This article examines how Russian SOS Villages are undergoing foster reform, which prescribes a transition from institutional care for children deprived of parental care to family care model. The article analyses the problems and transformations experienced by SOS Villages, outlining the aims, instruments, and priorities of the reform. Empirically, the article is based on qualitative investigation of two Russian SOS Villages. Officially, SOS villages have the status of non-state children's homes. However, they were originally conceptualised as a means to implement family care by specially arranged SOS families (headed by SOS mothers). Comparing the activities of SOS Villages with the theoretical concepts of development, resilience, and attachment shows that children raised in SOS Villages avoid the typical problems associated with institutional care. SOS families provide favourable conditions for socialisation, protection, overcoming of social isolation, while maintaining sustainable contact with a significant adult. The normative context created by Decree 481, which changed the status of children's homes, alongside innovations in family policy and the general upsurge of traditionalist discourse, has made SOS Villages vulnerable. As a result, they are forced to protect both forms of their existence: institutional and family. Despite their conceptual adherence to the goals of the reform, in the eyes of the state the SOS Villages remain institutional entities targeted for closure or transformation into temporary residences for children. My research shows that under these new conditions SOS Villages have developed various strategies of involuntary mimicry. The most significant is the re-registration of SOS families as foster families. This helps keep children with their SOS families but significantly increases the level of responsibility and risks for SOS mothers. SOS Villages have also developed new activities, which may be useful in these new conditions. The establishment of consulting

Elena Bogdanova - PhD (Kandidat Nauk) in Sociology, Research Fellow, Centre for Independent Social Research; Visiting Lecturer, University of Eastern Finland, European University at St. Petersburg, Russian Federation. Email: bogdanova.nova@gmail.com 
service platforms is one of these. The transformations taking place with the SOS Villages show that the reform is directed mainly, or solely, towards correcting the institutional level of the system. Due to multiple formal conflicts with newly emerging conditions, one of the most successful and experienced providers of family care for children without parental care has been left in a vulnerable position.

Key words: SOS Children's Villages, children without parental care, deinstitutionalisation reform, foster care, involuntary mimicry

DOI: 10.17323/727-0634-2017-15-3-395-406

\section{Introduction}

Since the beginning of the 2010s Russia has been experiencing remarkable transformations in the sphere of child protection, especially for children left without parental care. After the Soviet and immediate post-Soviet decades, which were dominated by the institutional approach, state social policy turned towards homebased, family forms of care for those children who are wards of the state. For years, the approach to the socialisation of children in socialist and post-socialist children's homes has been strongly criticised by both Russian and foreign scholars (Milligan 2007; IJzendoorn et al. 2008; Petranovskaia 2015). Recent reforms have heralded multiple transformations on both the legal and the institutional levels. Meanwhile, to be efficient, any reform needs critical analysis and evaluation to reveal: (1) the conceptual origins of the reform; (2) who initiated it and for what reason; (3) the development pathway of the reform and its purposes.

This article presents a view of the process of deinstitutionalisation through the lens of one particular organisation SOS Children Villages ${ }^{1}$, which were incorporated into the entire system of care for orphans and children left without parental care ${ }^{2}$ since the mid-1990s. Transplanted from the international practice, these Villages have always been a non-standard component of the Russian system for children left without parental care. Research on how the SOS Villages are managing in the shifting legislative and socio-political context may help to identify the main triggers of the reform, its foci, directions, and priorities.

Initially, SOS Villages were outside of the focus of my research, which was devoted to foster reform in contemporary Russia. I was familiar neither with the reality nor the ideals of the SOS Villages before this study. My first contact with

\footnotetext{
${ }^{1}$ The original idea behind SOS Children's Villages appeared as a response to the acute problem of orphanhood in post-WWII Europe. In 1949, the first SOS Village was established in Austria. Today, SOS Children's Villages are found throughout the world, with more than 500 villages in 132 countries, educating more than 60,000 children deprived of parental care.

2 In Russian normative discourse, a distinction is made between 'orphans' (children without living parents) and 'children left without parental care' (children having at least one living parent, but for some reasons deprived of parental care). This distinction is not dramatically important in case of this article, because children from both groups might live in SOS Villages.
} 
the SOS Villages took place simultaneously with my request for permission to visit the Villages. The empirical base of this research involves two cases. These are two SOS Villages located in the central region of Russia. My ethnographic notes were made during the five visits I paid to these villages. During my visits, I had the chance to observe regular everyday life in the villages, communication between the director, SOS mothers, and children, as well as housing arrangements. Although this article is based mainly on the information gathered during the interviews with the directors of the villages, additional empirical data (analysis of normative documents, web-sites of the Villages, documents presenting history of the SOS Villages in Russia) helped me to reconstruct a more holistic picture and deeper understanding of the on-going transformations in the SOS Villages.

The sequence of these interviews and the interval between them is important. The first interview was conducted in Village 1 at the end of 2014. The Village was established in 2000, and at the time of the interview it included 12 SOS families, headed by 12 SOS mothers, and about eighty children. The Village is headed by a director, and involves administrative staff, a psychologist, educators, an engineer, a driver, and a gardener. The so-called 'House of the Youth' (Dom molodiozhi) which offers post-orphanage support for children between fifteen and eighteen - is also available in the Village. The Village has its own minibus. The first visit showed the Village to be an outlying case, influenced in multiple ways by the deinstitutionalisation reform. Immediately after my first visit I decided to use this case as a lens to consider the reform itself and to extend my empirical research.

My second interview with the director of SOS Village 2 took place in June 2016. This Village is not only spatially closest to the nation's capital, but is also the oldest (in operation since 1994), and has the strongest contacts with professional and political communities in the central region of Russia, and more specifically in Moscow. It is difficult to directly compare the two interviews made in two different Villages, which were located in two different regions, and separated in time by one and half years. However, I consider two cases as two points in the continuum of one process, and some notes about transformations and challenges, facing the SOS Villages in different places and in different moments of the reform of deinstitutionalisation seem relevant and meaningful. At the time of the interview there were only fifty children in Village 2, though it has spaces for eighty. Several children from this SOS Village were rehomed from an SOS family to an ordinary family. Also, my second informant emphasised the partial conversion of SOS Villages towards counselling and supporting outside foster families. This type of activity was not even mentioned during the first interview in 2014. This suggests that in the intervening period SOS Villages in Russia underwent dramatic changes.

\section{Increased State Regulation of Foster Care after 2010}

In 2010, the problem of care for children in state institutions became more acute in Russian political debate, when the former Children's Ombudsman 
Pavel Astakhov addressed a question to the President during their annual teleconference. Astakhov described a scandal with a foster mother from the USA, Tory Hansen, who repatriated her foster son Artem Savel'ev to Russia due to health problems. Astakhov suggested a total ban on foreign adoption. Care for children left without parental care was identified publicly as a problem of the family, precisely as a problem of families inside Russia. It is also important that international scandal, rather than poor conditions in the state children homes catalysed the process of reform in this sphere. Greater attention to the problem of children was kindled by this adoption debate, and it had an impact on the further development of events.

Over the last five years, Russian legislation regulating the sphere of care for children left without parental care underwent multiple changes. In June 2012, the President adopted the National Strategy of Action for Children 2012-2017 (Presidential Order 2012). The National Strategy defined the main purposes of state policy towards child protection as follows: (1) prioritising family care for children left without parental care; (2) reforming institutions for children left without parental care, including children with disabilities (the Order did not suggest particular measures for reforming, but identified general request towards reduction of the role played by institutional forms of care about children left without parental care); (3) establishing a system of post-boarding support (Art. 1, 2, 5). The development of Children's Villages as a specific and successful form of care for children left without parental care was mentioned among the priorities in the National Strategy (Art. 5.3).

Another international scandal, provoked by the death of a Russian child in an American foster family in 2012, generated another wave of interest in the problems of child protection. Federal Law No.272, also known as the Dima Yakovlev Law, was signed on December 28, 2012. Among other restrictions, this Law imposed a ban on the adoption of Russian children left without parental care by American citizens (Art. 4). Finally, on May 24, 2014 the Russian Government adopted a Decree No.481 'On activities of organisations for children deprived of parental care, and about placement of children in these organisations'. The Decree acknowledged the need to prioritise family forms of care for children left without parental care, and recognised children's homes just as places for temporary stays. There had been attempts to prioritise family placements earlier (see, for example, Federal Law 1995: Art. 123), but as Meri Kulmala et al. show in this issue, several factors finally coincided to make things happen.

A review of the main changes to Russian legal regulations after 2012 shows that the general trend of on-going reforms surrounding the protection of children without parental care leans towards deinstitutionalisation. As Kulmala et al. show in their article in this issue, reformers unanimously support family forms of care, and simultaneously disparage the very idea of institutional care for children left without parental care. This turn towards deinstitutionalisation coincides with the desires of the expert community, which includes NGO leaders, 
psychologists, and educators. Despite professional debate and strong support from non-governmental organisations, foster care reform did not occur until political interests intervened into the process.

\section{Theories of Deinstitutionalisation versus the Original Conception of SOS Villages}

In this section, I consider the theoretical underpinnings of deinstitutionalisation, the purposes and opportunities of this process, and how they correlate with the forms of care provided by the SOS Villages in Russia. I consider deinstitutionalisation reform through several theoretical conceptions (Ismayilova et. al 2014: 136), comparing theoretical understandings of deinstitutionalisation with the original conception of Children SOS Villages. In particular, I examine how developmental (Elder et al. 2003; Erikson 1993), resilience (Fergus, Zimmerman 2005; Walsh 2002), and attachment (Bowlby 1969) theories consider questions of protection, convenient socialisation, and social inclusion of children deprived of parental care.

Theorists of child and adolescent development identify a range of developmental stages that children go through from childhood to adulthood to acquire the competencies and skills that allow them to successfully adapt to their social environment (Elder et al. 2003; Masten, Powell 2003; Erikson 1993). Separation from biological parents, isolation from society, childhood traumas, and maltreatment can interfere with normal developmental trajectories and disrupt children's natural passage through the developmental stages, potentially leading to emotional and behavioural problems, disruptive and acting out behaviours, social isolation or negative peer association, stigmatised selfidentity, and dependency (Dixon, Stein 2005; Kelleher et al. 2000).

Responding to development theory, resilience theorists posit that the disadvantages of institutional care can be compensated for (Masten, Powell 2003; Schofield, Beek 2005). A caring relationship with an adult is one of the most important sources of resilience in children and it can protect them from risktaking when they experience stress and adversity (Walsh 2002). Reintegrating children left without parental care back into society and giving them an opportunity to grow in a family environment may improve their psychosocial functioning and prevent mental health problems (Tarren-Sweeney 2008).

Attachment theory represents one of the most successful attempts to explain childhood emotional development. John Bowlby argued that emotional connections between a child and his or her adult caretaker help the child to develop complex reactions, which provide safeness (Schmidt 2016: 59). Forms of care based on attachment theory aim to develop relationships of attachment between a child and an important adult, whether a biological parent or any other person. Successful development of such relations requires personal contact, which can be achieved in the conditions of a foster home, or in small 
groups. It may be less successful in large children's homes where many children are looked after by one adult.

Directly or indirectly, all three theories support deinstitutionalisation, emphasising the importance of appropriate socialisation, social inclusion of children, and emotionally invested, long-term personal contact between an orphaned child and a significant adult. From the viewpoint of psychologists and sociologists (see, IJzendoorn et al. 2008; Petranovskaia 2015), the Soviet system of childcare and its heritage needs urgent and drastic reformation, pending complete destruction. Moreover, these theorists commonly and explicitly attribute all the negative consequences for child development to the conditions of children's homes. Thus, the theoretical debate, considered above, has reached a consensus. This is that hardly any institutional form is capable of fulfilling the requirements of normal child development. Family forms of care are described as more suitable for the goal of successful socialisation, providing close sustainable emotional connections between children and teachers, encouraging the formation of self-identity in children, and promoting social inclusion.

Following the main aim of the article, I examine how the original idea of SOS Villages looks from the viewpoint of these theories. For much of their existence, SOS Villages took various forms in different countries. In its classical form, an SOS Children Village was designed to be a children's home subsuming a number of SOS families, headed by professionally-trained caregivers. In most cases, the head of these villages is a SOS mother but in some countries, fathers or couples may head SOS families. In Russia, in particular cases an SOS family may be led by a couple, such as an SOS mother and her husband (the role of the mother is still fundamentally important, and 'SOS father' does not even exist in official terms). During my research, I met only SOS families headed by mothers. SOS mothers are responsible for guiding the family over the years, adhering to professional childcare standards. Living with children permanently, the mother aims to create emotionally stable relationships in a nurturing and secure home. An SOS mother receives the necessary support from the staff of a Village, which usually involves SOS 'aunts' as assistants, professional psychologists, and teachers. In international practice the official status of an SOS mother is identified as hired educational specialists in out-of-home care (SOS Children's Villages International 2016). It was the same in Russia until recently.

Thus, SOS Villages in Russia realise all the main principles of education for children deprived of parental care, as emphasised by the theorists. Living in the Villages, children have permanent long-term contact with an SOS mother, which is necessary for the development of sustainable emotional relations of attachment. Children live in families with their mother and six to eight other children. While separate, the Villages are not isolated from surrounding communities and settlements. Children visit regular schools, clubs, and local events. SOS mothers encourage the participation of children in household work. Children may visit nearby supermarkets and make simple purchases, 
gaining experience with handling money. The living conditions in both SOS Villages I observed are quite favourable. The families live in spacious cottages, with one room intended for one or two children. The cottages are well-equipped and furnished. The Village is located near a town and includes considerable green space, enclosed by fences. The territory is very clean, equipped with playgrounds. Living in the SOS Villages provides children with social inclusion, protection, and permanent contact with a significant adult.

Having the official status of children's homes, SOS Villages never matched the Soviet model of institutional care for children left without parental care in Russia. In fact, they maintained the family form of care from the moment they appeared in Russia. In the following sections I will consider what this contradiction means for SOS Villages in the context of Russian foster reform.

\section{Russian SOS Villages and the Trend toward Deinstitutionalisation}

SOS Children's Villages have always been an unusual element in the Russian welfare system for children without parental care. In this section I consider how the SOS Villages have weathered the foster reform.

\section{SOS Children's Villages in Russia: An Alien Element in the System}

The above-mentioned notion of the Children's Villages in the National Strategy of Action for Children 2012-2017 indicated significant support and legitimisation of this form of care for children deprived of parental care, and strengthened the position of the SOS Villages within the welfare system as a whole. That was a rare measure of encouragement of the Villages' activities. Relations between individual Villages and the administrative bodies are full of difficulties.In the eyes of the state, SOS Villages operate as an institutional form of care. Children are placed in SOS Villages through the same channels as for placement in state institutions. All the SOS Villages receive the same inspections as the state child welfare institutions. According to my interviewees, this is inappropriate for non-state children's homes, which have never had similar resources and capacities. For example, official sanitary regulations (Sanitarnye pravila 2000) prescribe outstandingly detailed rules for hygiene, feeding, medical services, physical training, living conditions, and other amenities which must be provided by a state children's home. The annual budget of an SOS Village does not allow for maintaining a staff of specialists, or for monitoring compliance of all these rules, while regular state children's homes can. Also, according to my interviews with the directors, some rules have been rendered redundant. For example, permitted foods are limited, which helps to avoid problems with digestion or allergies. As a result, residents of children's homes never eat some of the products enjoyed by children in regular families. Being restricted in their resources and trying to establish family-like life conditions, SOS Villages 
are forced to break certain rules. Being unable to meet the requirements of the inspectors, SOS Villages are forced to look for solutions in each case:

They follow a universal approach: all the children's homes must be checked in the same way. This is simply impossible in our case. We try to convince, to persuade, to show. I say: 'Do you feed your own children mayonnaise? Why should we not? This is the same mayonnaise, from the same supermarket' (Interview, Village 2).

Besides the direct laws regulating the care of children without parental care, SOS Villages are also affected by the traditionalist turn in family policy. In 2014, the Concept of the State Family Policy in the RF for the Period till 2025 was adopted (Directive of the Government of the Russian Federation 2014). The concept offers evidence of how neo-traditionalism increasingly characterises the transformation of gender relations in modern Russia. Zhanna Chernova claims that 'today this trend is perceived as dominant and the institutionalization of traditionalist discourse in family policy has become a fait accompli' (Chernova 2012: 91). This tendency shows, among other things, that the 'ideology of state policy creates patriarchal gender relations, idealizes traditional family model and ascribes it the highest value' (Ibid: 91). The Concept supports strictly heterosexual, two-parent, patriarchal family form, and marginalises all other family types. In this respect, SOS Villages risk being attacked by traditionalist and religious activists, who criticise the placement of children in single-parent families.

A particular official discourse about child protection is currently ascendant in Russia. The problem of children deprived of parental care is recognised as legitimate and extremely important on all state levels. The problem is also inscribed into the official discourses of demographic policy, protection of motherhood, and traditionalist family values. Such discursive support for the problem legitimises the efforts of NGOs protecting children deprived of parental care in general. However, contradictory regulations produce vulnerability, or, at least ambiguity for the SOS Villages.

SOS Villages do not contradict the general conceptual approach to care for children without parental care. On the contrary, they represent one of the most well-documented and consistent supporters of family care, attachment theory and methods of social inclusion. However, from the legislative perspective, the SOS Villages have to deal with contradictory institutional claims, legal norms, and official moral positions.

\section{Involuntary Mimicry}

As external conditions have become unfriendly, SOS Villages are forced to search for new strategies of self-representation in local communities and vis-à-vis the state, change their usual operational methods, and transform their plans for future development. The SOS Villages are experiencing essential 
difficulties in defining and safeguarding their status, and even with public signage around the Village: 'We have, for example, never announced the name of our Village. From outside it looks like a number of cottages' (Interview, Village 2). Such forced camouflage may promote the inclusion of children by local communities and prevent them from being stigmatised.

Multiple transformations at the institutional level entailed significant consequences for the SOS Villages. The growth of public concern with the topic of children left without parental care in early 2010s, and the subsequent 'Dima Yakovlev Law' led to changes in the SOS Villages' way of life. First of all, the formalisation of guardianship over pupils was encouraged by the organisation leadership. In some Villages, SOS mothers were forced to form foster families to conform with guidelines on fostering. Secondly, Decree No. 481 outlined the prioritisation of family over institutional forms of care. Since formally an SOS Village is seen as a children's home and hence children living there are available for adoption and/or placement with a foster family, in some cases this led to the unexpected and urgent withdrawal of children from SOS families:

Interviewee: They have received an order form the database for these two girls. They arrived here, got acquainted, invited the girls to visit, and were never brought back.

Researcher: Was everything so simple?

Interviewer: Yes, it was (Interview, Village 2).

As a result, all the SOS mothers in this Village formalised their guardianship over their children. From a legal perspective, the SOS Villages changed from being institutional children's homes into associations of foster families. SOS mothers were forced to head foster families, which meant a greater amount of responsibility and legal obligation towards the children in comparison with their former status as employed caregivers. At this moment, in the Russian SOS Villages two forms of families are available: SOS families, where the director of the Village is a trustee and legal guardian of all children, or foster families, where the legal guardians of children are their foster mothers and fathers.

The Village at this moment offers an intermediate form of care for children without parental care. It has the institutional and legal features of a children's home. Simultaneously, it operates as an association of foster families. My interviews with the directors of two Villages, and an overview of normative documents show that both the institutional and family forms of caregiving for orphans need protection. Director of one of the Villages in the interview defended the conception of institution care, applying lessons from history from both pre-Soviet and Soviet periods:

Children's homes resolved the problem of post-revolutionary homelessness, post-war neglect. That is, in institutions, in institutions, not in the family, and brought up in institutions, in the cadet corps, before the Revolution (Interview, Village 1). 
Current discourse generates a defensive position on the part of the SOS Villages. It encourages a very narrow set of practices governing the provision of care for children without parents. In fact, they are all reduced to the model in which the foster family is the central unit of caregiving, and all other forms are merely assistive. Just like experts in working with children deprived of parental care (Noskova et al. 2016:56-57), my interviewees see the necessity of different forms of care:

This is a paradox, of course, but not every child needs a family. There are children who do not want to go to a family. Especially teenagers older then fourteen or fifteen. A children's home with collective education may be preferable for them. $<\ldots>$ Therefore, we need different reforms (Interview, Village 2).

Simultaneously, the interviewees fervently defend single-parent families, headed by a mother. Incidentally, in the interview one of them described 'a mother' not as an identity, but as a profession:

The myth about the importance of male role models? Is a myth $!<\ldots>$ my grandmother raised my father and his younger sister. And in my imagination, in my knowledge, I'd say that these are women who in this country for decades and centuries raised their families alone. Because the men in this country die, or drink too much $<\ldots>$ A lioness is enough to raise a lion (Interview, Village 1).

SOS Villages are forced to correct their activities in accordance with the new external conditions, and balance between two statuses: that of children's home and that of an association of foster families. Legally, this may mean for them the necessity of manipulating the statuses of children, who may be officially recognised as orphans/children deprived of parental care, pupils of a children's home, or as children placed with foster families. The latter status meets the requirements of official regulations much better than the former.

\section{Reforming Institutional Design without a Change in Ideas?}

The imperfections of the Soviet and post-Soviet system for children left without parental care have been observed over a long period. The reform of deinstitutionalisation of the sphere, which entered the active phase in early 2010, had been long expected and was approved from the point of view of the dominant current theories of child and adolescent development. Although research shows that the main task of reform is the improvement of the children's well-being, this is not always the dominating concern in reformist measures. The starting point of the reform, which was catalysed by the third-party problems of internal and external politics, removed this from the main focus. Analysis of how a particular branch of SOS Villages goes through reform also shows the principles and priorities of these reform effort, the degree of its reasonableness, and preparedness. 
On the one hand, SOS Children's Villages are recognised as providing a positive form of caregiving for children deprived of parental care all over the world. In Russia, the Villages were also duly appreciated and included on the list of successful and worthy development projects by the National Strategy of Action for Children 2012-2017. SOS Villages, in fact, have developed family forms of care for children deprived of parental care in Russia for over twenty years. SOS Villages are one of the most experienced structures providing professional family care for children left without parental care in Russia, and are among the most faithful supporters of principles of deinstitutionalisation for such children.

On the other hand, the official status of non-governmental children's homes, their international origins, and the specificity of SOS families makes a dramatic difference, and leaves SOS Villages vulnerable in the context of contemporary Russian legal and moral regulations. The shift from institutional forms of care toward associations of foster families has placed the Villages in an intermediate position, whereby they are forced to justify both models: children's homes and parent-led families. Current normative, official, and moral discourses in Russia include criticism of each of these statuses. The prioritisation of family care for children deprived of parental care, proclaimed by the National Strategy, opens all institutional forms of care up to criticism. Family policy strictly defines the legitimate model of the family appropriate for raising children as the nuclear, heterosexual, two-parent form. All other types of families are vulnerable.

\section{Conclusion}

Strictly speaking, SOS Villages do not contradict the state policy of deinstitutionalisation at the level of their conceptual approach to care for children left without parental care. Simultaneously, they are forced to correct, hide, or camouflage their actual methods of work. The status of non-governmental children's home needs protection, as do those SOS families. Analysis of mimicry strategies implemented by SOS Villages reveals the priorities of the reform, which seeks to make corrections primarily on an institutional level. This means that the recent reforms have not matched up with the conceptual theoretical recommendations of deinstitutionalisation, but were driven mainly by the interests of the current political regime, which has decided to utilize the resources of traditionalism and international confrontation. This generates a major risk of focusing on superficial institutional reforms without an awareness of the underlying ideas behind them.

\section{References}

Bowlby J. (1969) Attachment and Loss: Attachment, London: Hogarth Press. Chernova Zh. (2012) New Pronatalism? Family Policy in Post-Soviet Russia. Region, 1 (1): 75-92. Decree of the Government of the Russian Federation (2014) O deyatel'nosti organizatsiy dlya detey-sirot i detey, ostavshikhsya bez popecheniya roditeley, i ob ustroystve $v$ nikh detey, os- 
tavshikhsya bez popecheniya roditeley [On the Activity of Organizations for Orphan Children and Children without Parental Care and on Placement of Children without Parental Care in Them] No. 481 from 24.05.2014.

Dixon J., Stein M. (2005) Leaving Care: Throughcare and Aftercare in Scotland, London: Jessica Kingsley Publishers.

Directive of the Government of the Russian Federation (2014) Ob utverzhdenii kontseptsii gosudarstvennoy semeynoy politiki $v$ RF na period do $2025 \mathrm{~g}$. [On Approval of the Concept of the State Family Policy in the RF for the Period till 2025] No. 1618-r from 25.08.2014.

Elder G. Jr., Johnson M., Crosnoe R. (2003) The Emergence and Development of Life Course Theory, J.T. Mortimer, M. J. Shanahan (eds.) Handbook of the Life Course, New York: Springer: 3-19. Erikson E. (1993) Childhood and Society, New York: WW Norton and Company.

Federal Law (1995) Semeinyi kodeks Rossiyskoy Federatsii [Family Code of the Russian Federation] No. 223-FZ from 08.12.1995.

Federal Law (2012) O merakh vozdeistviia na lits, prichastnykh $k$ narusheniiam osnovopolagaiushchikh prav I svobod grazhdan Rossiyskoy Federatsii [On Measures Against Persons Involved in Violations of Fundamental Human Rights and Freedoms of Citizens of the Russian Federation] No.272-FZ from 28.12.2012.

Fergus S., Zimmerman M. A. (2005) Adolescent Resilience: A Framework for Understanding Healthy Development in the Face of Risk. Annual Review of Public Health, (26):399-419.

IJzendoorn, M., Luijk M., Juffer F. (2008) IQ of Children Growing Up in Children's Homes: A Meta-Analysis on IQ Delays in Orphanages. Merrill-Palmer Quarterly, 54 (3):341-366.

Ismayilova L., Ssewamala F., Huseynli A. (2014) Reforming Child Institutional Care in the PostSoviet Bloc: The Potential Role of Family-based Empowerment Strategies. Children and Youth Services Review, (47): 136-148.

Kelleher P., Kelleher C., Corbett M., Press O. (2000) Left out on their Own: Young People Leaving Care in Ireland, Dublin: Oak Tree Press.

Masten A., Powell J. (2003) A Resilience Framework for Research, Policy, and Practice, S. S. Luthar (ed.) Resilience and Vulnerability: Adaptation in the Context of Childhood Adversities, Cambridge: Cambridge University Press: 1-25.

Milligan I. (2007) Residential Child Care Is Not Social Work! Social Work Education: The International Journal, 17 (3): 275-285.

Noskova A., Titova M., Vasil'ev A., Kishkin M. (2016) Deti vne sem'i: fosternye praktiki v Rossii [Children Out of Family: Foster Practices in Russia]. Sotsiologicheskie issledovaniia [Sociological Research], (8): 54-64.

Petranovskaia L. (2015) Taynaya opora. Privyazannost' v zhizni rebenka [Hidden Support. The Meaning of Attachment in a Life of a Child], Moscow: AST.

Presidential Order (2012) O natsional'noi strategii deistvii v interesakh detei na 2012-2017 gody [On the National Strategy of Action for Children 2012-2017] No. 761 from 01.06.2012.

Sanitarnye pravila (2000) Sanitary Regulations No. 2.4.990-00 from 01.11.2000. Available at: http://zakon.edu.ru/catalog.asp?ob_no=13041 (accessed 08 May 2017).

Schofield G., Beek M. (2005) Risk and Resilience in Long-term Foster-care. British Journal of Social Work, 35 (8): 1283-1301.

Schmidt V. (2016) Privyazannost' v deystvii: Psikhologicheskaya teoretizatsii svyazi rebenka i materi v (post)sotsialisticheskoy Chekhii [Attachment Theory in Action: Psychological Theories of mother-child bonding in post-socialist Czech Republic]. Laboratorium: Russian Review of Social Research, (1): 58-81.

SOS Children's Villages International (2016) SOS Children's Villages International Statutes. Available at: http://www.sos-childrensvillages.org/publications/publications/policies (accessed 18 July 2017).

Tarren-Sweeney M. (2008) The Mental Health of Children in Out-of-home Care. Current Opinion in Psychiatry, 21 (4): 345-349.

Walsh F. (2002) A Family Resilience Framework: Innovative Practice Applications. Family Relations, 51 (2): 130-137. 